\title{
Tıp Fakültesi Öğrencilerinin Akılcı İlaç Kullanımı Hakkındaki Düşüncelerinin Değerlendirilmesi
}

\author{
An Evaluation of the Medical Faculty Students' Thoughts on Rational Drug Use
}

\author{
Serkan ŞAHIN ${ }^{1}$, Şemsinnur GÖÇER ${ }^{2}$, Nursel Üstündağ ÖCAL ${ }^{3}$
}

\author{
${ }^{1}$ Yozgat Bozok Üniversitesi, Tip Fakültesi, Farmakoloji Anabilim Dal, Yozgat \\ ${ }^{2}$ Sarıkaya Fizyoterapi ve Rehabilitasyon Yüksekokulu, Yozgat \\ ${ }^{3}$ Yozgat Bozok Üniversitesi, Sağlık Hizmetleri Meslek Yüksekokulu, Yozgat
}

Geliş tarihi: 13.12.2019 Kabul tarihi: 29.01.2020 DOI: $10.17517 / \mathrm{ksutfd} .658572$

\section{Özet}

Amaç: Dünya Sağlık Örgütü akılcı ilaç kullanımını, "hastaların klinik ihtiyaçlarına uygun ilaçları, kişisel gereksinimlerini karşılayan dozlarda, yeterli bir süre boyunca, kendilerine ve topluma en az maliyet ile kullanmaları” olarak tanımlamıştır. Hastanın akılcı ilaç kullanımında, hekimin ve eczacının verdiği talimatlar doğrultusunda ilacını kullanması gerekmektedir. Akılcı ilaç kullanımında hekimlerin en önemli paydaşlardan bir olması nedeniyle, bu çalışmada hekim adayı olan Yozgat Bozok Üniversitesi Tıp Fakültesi öğrencilerinin akılcı ilaç kullanımına ilişkin düşüncelerinin değerlendirilmesi amaçlanmıştır.

Gereç ve Yöntemler: Araştırmanın evrenini, Yozgat Bozok Üniversitesi Tip Fakültesi’nin 1., 2. ve 3. sınıflarında öğrenim gören 182 öğrenci oluşturmakta idi. Veri toplama aracı olarak yaş, cinsiyet gibi sosyo-demografik özellikler ile akılcı ilaç kullanımını değerlendiren 22 soruluk anket formu kullanıldı. Araştırmaya katılmayı kabul eden 131 öğrenciyle araştırma tamamlandı. Verilerin istatistiksel analizinde sayı ve yüzdelik dilimler kullanıldı.

Bulgular: Öğrencilerin yaş ortalaması 20.2 \pm 1.2 idi ve \% 47.3’ü erkekti. Öğrencilerin yaklaşık üçte ikisi akılcı ilaç kullanımını hastaya uygun ilaç yazılması olarak tanımladı. Öğrencilerin yaklaşık yarısı akılcı ilaç kullanımı eğitimi aldıklarını ifade etti. Öğrenciler tarafından hekimlerce en sık ağrı kesici ilaçların yazıldı̆̆ı, akılcı ilaç kullanımına en büyük engelin yanlış tanı ve yoğunluktan hasta ile yeterince ilgilenememe olduğu belirtildi. Öğrenciler, akılcı ilaç kullanımında en önemli paydaşın hekimler olduğunu ve ayrıca aktarlar, televizyon, internet vb. yollarla bitkisel ürünlerin alınarak kullanılmasının, hastaya uygulanacak tedavi sürecinin başarısında olumsuz etkisinin olduğunu ifade etti.

Sonuç: Sağlık otoriteleri tarafından; hekimlerin hastası için ayırdığı muayene süresini yeterli düzeye getirecek tedbirlerin (hekim başına düşen hasta sayısı gibi) alınması, ayrıca OTC (Over the counter ) ilaçlar ve reçeteyle satılan ilaçlar konusunda antibiyotiklerde olduğu gibi geri ödeme sisteminde reçete mecburiyeti kapsamının genişletilmesi akılcı ilaç kullanımına katkı sağlayabilir.

Anahtar Kelimeler: Akılcı ilaç kullanımı, Hekim, Tıp Fakültesi, Üniversite öğrencisi

\section{Abstract}

Objective:

The World Health Organization has defined rational druguse as "patients receive medications appropriate to their clinical needs, in doses that meet their own individual requirements, for an adequate period of time, and at the lowest cost to the mand their community." Inrational drug use, patients should use their drugs in accordance with the instructions given by physicians and pharmacists. Due to a physician to be the most important stakeholders in rational drug use. In this study, it is aimed to evaluate the thoughts of medical faculty students of physician candidate in Yozgat Bozok University on rational druguse.

Material and Methods: The population of the study consisted of 182 students studying at the 1st, 2nd and 3rd grades of Yozgat Bozok University Faculty of Medicine. As a data collection tool, a 22-question questionnaire was used to evaluate. Rational Drug Use and socio-demographics such as age, gender. The study was completed with 131 students who agreed to participate in the study. Number and percentage slices were used for statistical analysis of the data.

Results: The average age of the students was $20.2 \pm 0,2$, and $47.3 \%$ of them were male. Approximately two-thirds of the students defined rational druguse as appropriate drug prescribing for patients, and nearly half of them stated that they had had rational druguse education. It was stated that the most frequently prescribed drugs by physicians were analgesics, and the biggest obstacle to rational drug use was the inability to take care of the patient adequately due to misdiagnosis and high number of patients. The students indicated that the most important partners in rational drug use are physicians, and taking herba lproducts via herbalists, TV, internet, etc affected the success of the treatment process of patients in a negative way.

Conclusion:By the health authorities; taking measures (such as the number of patients per physician) to ensure that the examination period reserved by physicians for the patient is sufficient, in addition, OTC (Overthecounter) drugs and prescription drugs, such as antibiotics in the reimbursement system, such as expanding the scope of prescription obligation may contribute to rational drug use.

Key Words: Rational Drug Use, Physician, Faculty of Medicine, University student 


\section{GİRIŞ}

Günümüzde sunulmakta olan sağlık hizmetlerinin asıl amacı toplumu hastalıklardan korumaktır. Bununla birlikte gösterilen tüm çabaya rağmen toplumdaki bütün bireyleri hastalıklara karşı korumak imkansızdır ve bu durumda sağlık hizmetlerinin ikinci amacı olan hastaların tedavisi olgusu ön plana çıkmaktadır (1). Hasta tedavisinin en önemli bileşenlerinden biriside ilaç kullanımıdır.

Dünya Sağlık Örgütü (DSÖ) ilacı; "Fizyolojik sistemleri ve patolojik durumları alanın yararı için değiştirmek veya incelemek amacıyla kullanılan veya kullanılması öngörülen bir madde veya ürün" olarak tanımlamaktadır (2). İlaçlar hastalıkların teşhisinde, tedavisinde ve bazı hastalıklardan korunmak için gerekli maddelerdir. Hastalıklar cerrahi olarak tedavi edilse dahi destekleyici olarak bazı ilaçların da kullanılması gerekmektedir. İlacın koruyucu ve tedavi edici etkilerinin yanında oluşturabileceği yan etkilerin varlığı ve sağlık harcamalarında önemli bir payı olması, ilaç kullanımını daha da önemli hale getirmektedir (3-6).

Akılcı olmayan ilaç kullanımı, başta gelişmekte olan ülkeler olmak üzere tüm ülkelerin önemli bir sağlık sorunudur ve düzeltilmesi güç bir alışkanlık olarak kabul edilmektedir. Gereksiz ve yanlış ilaç uygulaması ölümle de sonuçlanabilen ciddi birçok sağlık sorununa sebep olabilmektedir (7).

DSÖ tarafından 1985 yılında Nairobide düzenlenen toplantıda akılcı ilaç kullanımı (AİK), "hastaların klinik ihtiyaçlarına uygun ilaçları, kişisel gereksinimlerini karşılayan dozlarda, yeterli bir süre boyunca, kendilerine ve topluma en az maliyet ile kullanmaları" olarak tanımlanmıştır (7).

AİK'ya baktığımızda, bu ilkeleri yerine getirebilecek bilgi ve tecrübeye sahip olan kişilerin hekimler oldukları aşikardır. Hastanın durumunu etkin bir şekilde araştırıp hastalığa yönelik tanıyı belirledikten sonra en uygun ilacı seçen, bunlara göre reçete yazan yetkili kişilerin hekimler olması AİK hususunda sorumluluğun en fazla hekimlerde olduğunu göstermektedir (8). Ancak, sadece hekimin AİK konusunda uygun hareket etmesi, hassasiyet göstermesi yeterli değildir. Çünkü hekimin yazdığı reçeteye hastanın uyum göstermemesi, hastanın ilacını saatinde kullanmaması, kullanması gereken süreden daha erken bırakması, ilacın aç-tok kullanımına dikkat etmemesi, ilacını su dışında başka içeceklerle alması gibi durumlarda hekimler üzerine düşen görevi yerine getirseler bile tedavinin başarılı olması mümkün olmayabilir (9).

Hastanın, gerek hekimin gerekse de eczacının verdiği direktiflere uygun olarak ilacını kullanmasında toplumdaki diğer bireylerinde sorumluluğu olduğu bilinen bir gerçektir. Dolayısıyla AİK konusu, sadece hekimleri içine alan bir konu değildir. Hekim, hasta, hasta yakını, eczacı, hemşire ve diğer sağlık çalışanları ile hatta kurum ve kuruluşları da kapsayan bir konudur. Her ne kadar birçok paydaşın varlığından söz edilsede AİK'da asıl paydaşlar hekim ve hastalardır (9).

İlaçların reçetesiz yada yakın çevrenin önerisi ile kullanımi, ilacı uygun koşullarda saklamama, son kullanım tarihine dikkat etmeme gibi sorunların karşımıza çıkarmasının yanı sıra bireylerin AİK ile ilgili bilgi düzeyinde eksikliğinin olması konunun önemini daha da artırmaktadır (9).

Bu çalışmada hekim adayı olan Yozgat Bozok Üniversitesi Tip Fakültesi öğrencilerinin AİK hakkındaki düşüncelerinin değerlendirilmesi amaçlanmıştır.

\section{GEREÇ VE YÖNTEMLER}

\section{Araştırmanın Tipi:}

Araştırma, Yozgat Bozok Üniversitesi Tip Fakültesi öğrencilerinin mezuniyet öncesi AİK'ya ilişkin düşüncelerinin değerlendirilmesine yönelik tanımlayıcı kesitsel tipte bir çalışmadır. Çalışma için Yozgat Bozok Üniversitesi Klinik Araştırmalar Etik Kurulu 2017-KAEK-189-2019.06.19-01karar numarası ile izin alınmıştır.

\section{Araştırmanın Evreni:}

Tanımlayıcı ve kesitsel nitelikte olan bu çalışmada 20182019 eğitim-öğretim yılı bahar döneminde Yozgat Bozok Üniversitesi Tip Fakültesi’nde ilk üç sınıf olması ve fakültedeki öğrenci mevcudunun 182 öğrenci olması nedeniyle örneklem seçimine gidilmeyip evrenin tamamına ulaşılması hedeflendi. Çalışma, araştırmaya katılmayı kabul eden 131 öğrenci ile tamamlandı.

\section{Veri Toplama Araçları:}

Araştırmacılar tarafından iki bölümden ve 22 kapalı uçlu sorudan oluşan anket formu hazırlandı. Formun ilk bölümünde yaş, cinsiyet gibi sosyo-demografik özellikleri sorgulayan sorular, ikinci bölümde ise AİK'yı değerlendirmeye yönelik sorular yer almaktaydı. Katılımcılardan her soru için bir şık işaretlemeleri istendi. Araştırma, anket sorularına katılımcıların kendi sınıflarında cevap vermeleri sağlanarak gerçekleştirildi.

\section{Verilerin Analizi:}

Veriler sayı ve yüzdelik dilimler olarak ifade edildi.

\section{BULGULAR}

Öğrencilerin yaş ortalaması $20.2 \pm 1.2$ yll, \%47.3'ü erkek idi (Tablo 1). Araştırmaya katılan öğrencilerin \%41.2'si dönem 1 , \%32.8'i dönem 2 ve $\% 26.0^{\prime} 1$ ise dönem 3 öğrencilerden oluşmaktaydı.

Öğrencilerin \%44.6’sı eğitimleri sırasında AİK eğitimi aldıklarını ifade etti. Öğrencilerin \%64.1'i AİK'yı hastaya uygun ilaç yazılması olarak tanımlarken $\% 9.8$ 'i hastaya güvenli ilaç yazılması, \%9.2'si hastaya etkili ilaç yazılması şeklinde tanımladı. İlaç yazarken göz önünde bulundurulması gereken en önemli hususun \%74.0 oranla uygunluk olduğu ifade edildi. Reçete yazarken "Birinci Basamağa Yönelik Tanı ve Tedavi Rehberleri" kullanılmalı diyenlerin oranı $\% 85.5$ idi (Tablo 2). 


\begin{tabular}{|c|c|c|c|}
\hline \multicolumn{2}{|l|}{ ÖZELLİKLER } & Sayı & $\%$ \\
\hline \multirow{6}{*}{ Yaş Grupları } & 18 & 14 & 10,7 \\
\hline & 19 & 18 & 13,7 \\
\hline & 20 & 44 & 33,6 \\
\hline & 21 & 40 & 30,5 \\
\hline & 22 & 12 & 9,2 \\
\hline & 23 & 3 & 2,3 \\
\hline \multirow{2}{*}{ Cinsiyet } & Kadın & 69 & 52,7 \\
\hline & Erkek & 62 & 47,3 \\
\hline \multirow{3}{*}{ Sinif } & 1 & 54 & 41,2 \\
\hline & 2 & 43 & 32,8 \\
\hline & 3 & 34 & 26 \\
\hline Toplam & 131 & 100 & \\
\hline
\end{tabular}

\section{Tablo 2. AIIK ile ilgili sonuçların dağılımı}

Sorular

AİK eğitimi alma durumu (n:130)

Akılcı ilaç kullanımı nedir?(n:131)

İlaç yazarken göz önünde

bulundurulması gereken ne önemli husus hangisidir? (n:131)

Reçete yazarken, "Birinci Basamağa Yönelik Tanı ve Tedavi Rehberleri” kullanılmalı mı? (n:130)

Hekimlerce en sık yazılan ilaç grubu (n:131)

AİK kullanımına engel olan nedenler (n:128)

\begin{tabular}{|c|c|c|}
\hline & $\mathrm{N}$ & $\%$ \\
\hline Hayır & 72 & 55,4 \\
\hline Evet & 58 & 44,6 \\
\hline Hastaya uygun ilaç yazılması & 84 & 64,1 \\
\hline Hastaya güvenli ilaç yazılması & 13 & 9,8 \\
\hline Hastaya etkili ilaç yazılması & 12 & 9,2 \\
\hline Uygun dozda ilaç yazılması & 9 & 6,9 \\
\hline Diğer & 9 & 6,9 \\
\hline Uygun süre ilaç kullanımı & 4 & 3,1 \\
\hline Uygunluk & 97 & 74 \\
\hline Etkinlik & 14 & 10,7 \\
\hline Güvenlilik & 12 & 9,2 \\
\hline Hasta istekleri & 5 & 3,8 \\
\hline Maliyet & 2 & 1,5 \\
\hline İlaç mümessili tanıtımı & 1 & 0,8 \\
\hline Evet & 111 & 85,5 \\
\hline Hayır & 19 & 14,5 \\
\hline Ağrı kesiciler & 91 & 69,5 \\
\hline Antibiyotikler & 35 & 26,7 \\
\hline Tansiyon ilaçları & 2 & 1,5 \\
\hline Diğer & 2 & 1,5 \\
\hline Kalp İlaçları & 1 & 0,8 \\
\hline Yanlış tanı & 37 & 28,9 \\
\hline $\begin{array}{l}\text { Hasta yoğunluğundan yeterince hastayla } \\
\text { ilgilenememe }\end{array}$ & 34 & 26,6 \\
\hline İlaç sonrası hasta takibi yapmama & 19 & 14,8 \\
\hline İlaç kullanımına ilişkin bilgi eksikliği & 15 & 11,7 \\
\hline Yeterince hastayı bilgilendirmeme & 9 & 7 \\
\hline Çok sayıda preparat ve jenerik varlığı & 6 & 4,7 \\
\hline Hastanın 1srarı & 4 & 3,1 \\
\hline $\begin{array}{c}\text { Sağlık Bakanlığı'nın hasta bazlı veri sisteminin } \\
\text { yetersizliği }\end{array}$ & 3 & 2,3 \\
\hline İlaç mümessillerin teşviki & 1 & 0,8 \\
\hline $\begin{array}{l}\text { Akılcı ilaç kullanımına dair veri sisteminin } \\
\text { geliştirilmesi }\end{array}$ & 49 & 37,4 \\
\hline Kamu spotu & 38 & 29 \\
\hline $\begin{array}{l}\text { Hekim bazlı e- reçete üzerinden Hekimlerin } \\
\text { değerlendirilmesi }\end{array}$ & 20 & 15,3 \\
\hline Hizmet içi Eğitim & 16 & 12,2 \\
\hline Diğer & 5 & 3,8 \\
\hline
\end{tabular}

AİK konusunda Sağlık Bakanlığg'nca yapılması beklenenler (n:128) 


\begin{tabular}{|c|c|c|c|}
\hline \multirow{6}{*}{ AİK'te en önemli paydaş (n:128) } & Hekim & 70 & 54,7 \\
\hline & Hasta & 41 & 32 \\
\hline & Eczaci & 8 & 6,3 \\
\hline & Hasta yakını & 7 & 5,5 \\
\hline & Hemşire & 1 & 0,8 \\
\hline & Diğer & 1 & 0,8 \\
\hline \multirow{5}{*}{$\begin{array}{l}\text { Endikasyonu olmayan durumlarda ilaç } \\
\text { yazmayı etkileyen faktörler (n:129) }\end{array}$} & Hastanın şikayetleri geçmediği için & 55 & 42 \\
\hline & Hiçbir zaman yazmam & 39 & 29,8 \\
\hline & Hasta 1srarı & 26 & 19,8 \\
\hline & Diğer & 6 & 4,6 \\
\hline & İlaç mümessili tanıtımları & 3 & 2,3 \\
\hline \multirow{2}{*}{$\begin{array}{l}\text { Muadil ilaç seçme yetkisinin eczacıda } \\
\text { olması doğru mudur? (n:128) }\end{array}$} & Hayır & 84 & 65,6 \\
\hline & Evet & 44 & 34,4 \\
\hline \multirow{5}{*}{$\begin{array}{l}\text { Katılımcıların eczacıların ilaç danışmalı̆̆ı } \\
\text { yapmaları hakkındaki düşünceleri } \\
\text { (n:128) }\end{array}$} & Yetersiz, kısmen ilaç danışmanlığı yapılıyor & 67 & 52,3 \\
\hline & İyi derecede ilaç danışmanlığı yapılıyor & 29 & 22,7 \\
\hline & Fikrim yok & 19 & 14,8 \\
\hline & Hiç ilaç danışmanlığı yapılmıyor & 12 & 9,4 \\
\hline & Diğer & 1 & 0,8 \\
\hline \multirow{3}{*}{$\begin{array}{l}\text { Eczacının muadil ilaç tavsiye etmesinin } \\
\text { tedavinin başarısına olumsuz etkisi } \\
\text { olduğunu düşünüyor musunuz? (n:127) }\end{array}$} & Bazen & 66 & 52 \\
\hline & Evet & 55 & 43,3 \\
\hline & Hayır & 6 & 4,7 \\
\hline \multirow{2}{*}{$\begin{array}{l}\text { Bitkisel ürün kullanımının tedaviyi } \\
\text { olumsuz etkilediğini düşünüyor } \\
\text { musunuz? (n:128) }\end{array}$} & Evet & 102 & 79,7 \\
\hline & Hayır & 26 & 20,3 \\
\hline
\end{tabular}

Öğrenciler tarafından, hekimlerce en sık yazılan ilaç grubunun \%69.5 ile ağrn kesiciler olduğu belirtildi. AİK’ya en büyük engel olarak \%28.9 oranla yanlış yada eksik tanı (ampirik tedavi, yeterli anamnez almama ve laboratuvar testlerini kullanmama vb.) ve \%26.6 oranla hasta yoğunluğundan yeterince hastayla ilgilenememenin sebep olduğunu ifade ettiler. Öğrencilerin \%37.4’ü Sağlık Bakanlığı tarafından akılcı ilaç kullanımına dair veri sisteminin geliştirilmesini, \%29.0'1 kamu spotu hazırlanmasını istemiştir. Öğrencilerin \% 54.7'si AİK'da en önemli paydaşı hekimler, \%32.0' ise hastalar olduğunu düşünmekteydi. Endikasyonu olmayan durumlarda hiçbir zaman ilaç yazmam diyenlerin oranı \%29.8 idi (Tablo 2).

Öğrencilerin \%65.6'sı reçetede yazılan ilaca muadil preparatların hastalara verilmesi konusunda ilaç seçme yetkisinin eczacılara verilmesinin tedavinin başarısı açısından yanlış olduğunu, \%52.3'ü eczacıların yetersiz ya da kısmi ilaç danışmanlığı yaptığını ifade etti. Eczacının muadil ilaç tavsiye etmesinin tedavinin başarısına olumsuz etkisinin olup olmadığ sorusuna katılımcıların \%52.0’si “Bazen” cevabının verirken, \%43.3'ü “Evet” cevabını verdi. Öğrencilerin \%79.7si aktarlar, TV, radyo, internet vb. yollarla bitkisel ürünlerin alınarak kullanılmasının, hastaya uygulanacak tedavi sürecinin başarısında olumsuz etkisinin olduğunu ifade etti (Tablo 2).

Şekil 1'de öğrencilerin hastaya reçete yazarken sorgulanması gerekli durumlar hakkındaki düşüncelerine ilişkin sonuçlar yeralmaktadır.
Öğrencilerin yarıdan fazlası, hastaların kullandığı ilaçların, ilaç alerjisi olup olmadığının, karaciğer, böbrek ya da kronik bir hastalığı olup olmadığının, gebelik durumunun ve yaşın; yaklaşı \% $45.0^{\prime} 1$ ise cinsiyetin dikkate alınarak her zaman sorgulanması gerektiğini ifade etti.

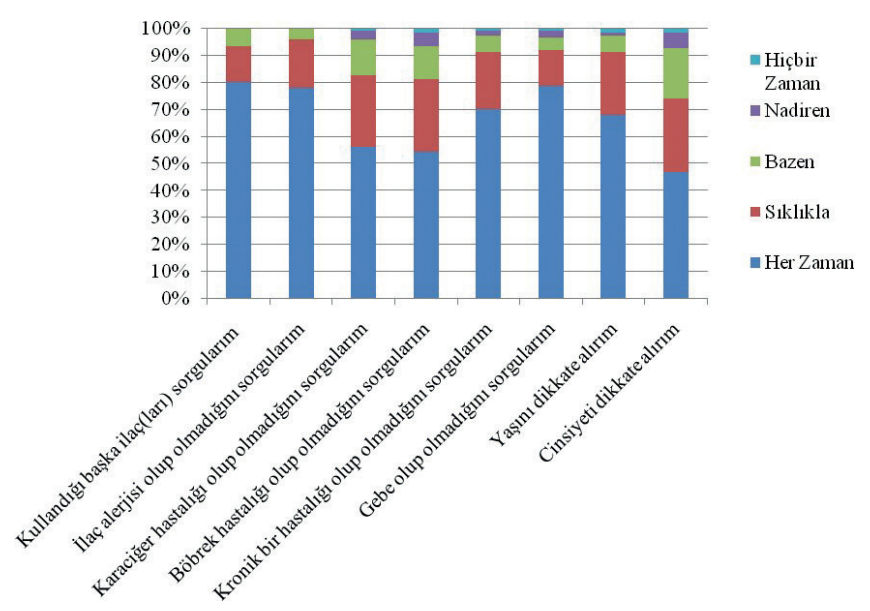

Şekil 1. Öğrencilerin hastaya reçete yazarken sorgulanması gerekli durumlar hakkındaki düşünceleri

\section{TARTIŞMA}

Sağlık harcamaları arasında ilaca fazla pay ayrılmasının sebepleri; tedavi edici sağllk hizmetlerine öncelik verilmesi, ilaç sanayisinde dışa bağımlılık, antibiyotiklerin fazla kullanımı vb. sayılabilir. Akılcı olmayan ilaç kullanımının ekonomik boyutunun fazlalığı, özellikle kaynakların verimli 
kullanılmasının gerekli olduğu günümüzde önemli bir sorun olarak karşımıza çıkmaktadır (10).

2002-2012 yılları arasında yıllık ortalama \%6.6 büyüyerek 515 milyar dolardan 972 milyar dolara tırmanan dünya ilaç pazarının, önümüzdeki dönemde de dünya nüfusunun artışı, yaşlanma ve diğer faktörlerin de etkisiyle büyümeye devam edeceği belirtilmektedir (11). 2018>de dünya genelinde ilaç sanayine yönelik harcamalar 1 trilyon 200 milyar dolar seviyesinde gerçekleşirken, 2019〉da bu rakamın \%5 artışla 1.3 trilyon dolara, önümüzdeki 5 yılda ise 1.5 trilyon dolara çıkması bekleniyor. Ülke bazında harcamalara bakıldığında ise ilk sırada Amerika Birleşik Devletleri (ABD) öne çıkarken, bunu Çin ve Japonya izliyor. En büyük paya sahip 5 ülke, 2018 itibarıyla 1.2 trilyon dolar büyüklüğe ulaşan dünya ilaç pazarının üçte ikisini oluşturuyor. Ülkemizde ise 20102018 yılları arasındaki 9 yıllık dönemde ilaç pazarının 2010 yılındaki 13.39 milyar TL düzeyinden \%131 oranında artışla 2018 yılında 30.94 milyar TL düzeyine ulaştığ tedir (12).

Çalışmamızda öğrencilerin "AİK nedir" sorusuna verdikleri cevaplar değerlendirildiğinde yarıdan fazlasının (\%64.1) AİK’yı hastaya uygun ilaç yazılması olarak tanımlamaları AİK’nın tanımı konusunda öğrencilerin bilgi sahibi olduklarını göstermektedir.

Maxwell(13) çalışmasında hekimlerin; klinik etkinliği arttırmak, zararı en aza indirmek, kaynakları verimli kullanmak gibi hususlara dikkat etmesinin gerektiğini ifade etmiştir. Demirkıran ve Şahin'in (14) çalışmalarında hekimlerin \%96.8'inin reçete yazımında "ilacın güvenliği (yan etki profili)” ve \%98.4'ünün “ilacın hastaya uygunluğu” göz önünde bulundurduklarını ifade etmişlerdir. Literatüre benzer şekilde, çalışmamıza katılan hekim adayı öğrencilerin \%74’ü ilacın hastaya uygunluğunun, \%10.7'si ilaç etkinliğinin ve \%9.2'si ise ilaç güvenliliğinin hastaya ilaç yazarken göz önünde bulundurulması gerektiği düşüncesindedirler.

Çalışmamızda öğrencilerin \%85.5’i reçete yazarken hekimlerin Sağlık Bakanlığı tarafından yayımlanan "Birinci Basamağa Yönelik Tanı ve Tedavi Rehberleri” kullanmaları gerektiğini belirtmişlerdir. Demirkıran ve Şahin'in (14) çalışmasında bahsi geçen rehberlerin kullanılmasının hekimlerin ilaç seçiminde etkili olduğu belirtilmiştir. Prosser ve diğerlerinin (15) İngiltere'de yaptığı çalışmada da bölgesel veya ulusal reçeteleme rehberlerinin ilaç seçiminde son derece etkili olduğu, diğer eğitim amaçlı yazılı bilgilerin ise reçete yazma davranışına etkisinin sınırlı olduğu belirtilmektedir. Çalışmamız sonucunda bahsedilen rehberlerin kullanılmasının gerekliliğinin katılımcıların büyük çoğunluğunca kabul edilmesi aslında literatürde vurgulanan benzer rehberlerin ilaç seçimde etkili olduğu ifadesi ile uyumludur. Çünkü AİK’da önemli hususlardan biriside ilaç seçimidir ve literatürlerdeki, ilaç seçiminde rehberlerin etkili olduğu ifadesi göz önünde bulundurulursa aslında rehberlerin kullanılmasının bir gereksinim olduğu kanaati oluşmaktadır. Bu durum ise çalışmamızda elde ettiğimiz sonuçla uyumludur.
Çalışmamıza katılan hekim adayı öğrencilere göre; hekimlere ilişkin akılcı ilaç kullanımına engel olan nedenlerin dağılımına baktığımızda yanlış tanının \%28.9, hasta yoğunluğundan yeterince hastayla ilgilenememenin \%26.6 ve ilaç sonrası hasta takibi yapmamanın ise \%14.8 etkili olduğu belirtilmiştir. Yukarıdaki oranlardan da anlaşılabileceği üzere çalışmamıza katılan öğrencilerin çoğunluğu AİK’na en büyük engelin; doğru tanının konulmaması olduğunu belirtmişlerdir. Çünkü, hekimler gerek ön tanı yetersizliği (laboratuvar, radyografi, kültür sonucu olmadan ampirik tanı) ve gerekse de hastayla yeterli süre ilgilenememeye bağlı olarak yanlış tanı konulması gibi sorunlarla karşılaşılabilmektedirler. Refik Saydam Hıfzıssıhha Merkezi Başkanlığı Hıfzıssıhha Mektebi Müdürlügü tarafından yapılan bir araştırmada (16) reçetelere yazılan ilaçların terapötik uygunluğu ve maliyeti baz alınarak birlikte değerlendirildiğinde, uygun reçetelenen ilaçların \%39.7 ve uygun reçetelenmeyen ilaçların ise \%60.2 oranında olduğu tespit edilmiştir ve bu bulgu, çalışmamızdan elde ettiğimiz sonucu da destekler niteliktedir.

Çalışmamızda hekim adayı öğrencilerin \%54.7'si akılcı ilaç kullanımında en önemli paydaşın hekim olduğu düşüncesinde iken \%32'si hasta, \%6.3'ü eczacı, \%5.5'i hasta yakını olduğu düşüncesindedir. Öğrencilerin bu düşüncesine uygun olarak Altındiş’in (10) çalışmasında akılcı ilaç kullanımında hekim, eczacı, hemşire ve diğer sağlık çalışanları, hasta ve hasta yakınları, devlet, ilaç endüstrisinin paydaşlar arasında olduğunu ancak bu paydaşlar içinde akılcı ilaç kullanımında önemli rolü hekimin üstlendiğini ifade etmektedir.

Çalışmamızda öğrenciler, endikasyonu olmayan durumlarda, ilaç yazmada hekimi etkileyen durumlarla ilgili olarak; \%42.0'1 hastanın şikayetlerinin geçmemesi, \%19.8'i ise hastanın 1srarı olduğunu belirtmişlerdir. Endikasyon olmayan durumlarda "hiçbir zaman yazmam" diyenlerin oranı ise \%29.8'dir. Çalışmamızla benzer şekilde Demirkıran ve Şahin'in (14) çalışmalarında, büyük oranda hasta talep ve beklentilerinin hekimlerin ilaç seçimlerinde etkili olduğunu belirtmişlerdir. Çalışmamızdan elde ettiğimiz sonuçlara göre, hastanın şikayetlerinin geçmemesi ve endikasyon olmayan durumlarda hiç bir zaman ilaç yazmam diyenlerin oranı ilk iki sırada yer alsa da, hekimin ilaç yazarken hastanın ısrarını ve beklentilerini karşılama ihtiyacı duyduğu da anlaşılmaktadır. Hekimlerin ve hekim adaylarının hastaya ilaç yazarken AİK kurallarının yanı sıra, hasta ihtiyaç ve beklentilerini de göz önünde bulundurarak ilaç yazmalarının en önemli nedeni olarak sağlıkta şiddet gösterilebilir. Çünkü hastanın, ilaç beklenti ve taleplerinin karşılanmaması halinde, hekim ve diğer sağlık çalışanlarına hasta ve hasta yakınları tarafından şiddet uygulanma olasılığı hekimi, endikasyonu olmasa da hastanın istediği ilacı yazmaya sevk etmektedir. Çünkü henüz hasta ile karşı karşıya gelmemiş ve herhangi bir hasta tarafından şiddete maruz kalmamış hekim adaylarının ya sosyal medya ya da meslektaş olacakları büyüklerinden duydukları olaylardan etkilenmeleri onlarda da çaresizlik oluşturmuş gibi görünmektedir. 
Çalışmamıza katılan hekim adayı öğrencilerin \%65.6'sı reçetede yazılan ilaca muadil diğer jenerik preparatların hastalara verilmesi konusunda, ilaç seçme yetkisinin eczacılara verilmesinin tedavinin başarısı açısından yanlış olduğu görüşündedir. Yine öğrencilerden; "Reçetede yazılan ilaç yerine, eczacının önerisiyle muadil ilacı kullanan hastalarda tedavi başarısında azalma olduğunu düşünüyor musunuz?" sorusuna "bazen" cevabinı verenlerin oran1 \%52 iken "evet" cevab1$\mathrm{n} 1$ verenlerin oran 1 ise $\% 43.3 \mathrm{idi}$.

Toklu ve Dülger(17), AİK’da eczacının temel görevleri arasında "ilaç önermeye" de yer vermekte, fakat ilaç önerme konusunda; eczacıların sıklıkla hastaya ilaç danışmanlığı yaptığını ve birçok ülkede OTC (overthecounter) ilaçları önerebildiği ve satabildiğini belirtmektedirler. Ancak, ülkemizde OTC ilaçlar ve sadece reçeteyle satılan ilaçlar konusunda eczacının önerisi açısından bir ayrım maalesef uygulanmamaktadır. Hasta, hekime danışmadan her iki ilaç türünü de reçetesiz alabilmektedir. Oysa ki eczacı OTC ilaçları önerebilir, ancak reçete ile satılması mecbur olan ilaçları reçetesiz satmaması gerekir (17). Araştırmadan elde edilen sonuca göre öğrencilerin, eczacının hastalık tanısı koyan ve bu tanıya uygun içerikteki ilacı reçete eden hekimin kararına uygun bir biçimde, reçete edilen ilacı tam ve eksiksiz olarak vermesinin tedavinin başarısı için gerekli olduğunu savundukları anlaşılmaktadır.

- Etkisiz, yüksek maliyetli, yanlış ve gereksiz ilaç kullanımı konusunda geleceğin hekimleri olan Tip Fakültesi öğrencilerinin düşüncelerinin değerlendirilmesi son derece önemli bir konudur. Araştırmadan elde edilen sonuçlar doğrultusunda;

- Ülkemizde Sağlık Bakanlığı tarafından ilki 2003 yılında çıkarılan "Birinci Basamağa Yönelik Tanı ve Tedavi Rehberleri”nin düzenli olarak güncellenmesinin,

- Toplumun ilaç seçimde en önemli otoritenin hekim olduğu fikrine alıştırılmasına yönelik eğitim ve farkındalık çalışmalarının yapılmasının,

- AİK'da doğru tanı, tanıya ve hastaya uygun doğru ilaç seçimi önemli bir kriterdir. Bu kapsamda sağlık otoriteleri tarafından gerekli laboratuvar altyapısının oluşturularak bu imkana ulaşılabilirliğin sağlanması ve hekimlerin hasta muayenesi için ayırmış oldukları zamanı uygun seviyelere getirecek düzenlemelerin yapılmasının,

- Tip Fakültesi öğrencilerinin ders müfredatlarına AİK konusunun eklenmesinin, AİK’ya katkı sağlaması bakımindan önemli olduğu düşünülmektedir.

Çıkar Çatışması ve Finans Durumu: Çalışmamız bir kurum ve kuruluşça finanse edilmemiştir. Bu çalışmada yazarlar arasında herhangi bir konuda çıkar çatışması bulunmamaktadir.

\section{KAYNAKLAR}

1. Baykan Z, Naçar M, Ulusoy HB. Erciyes üniversitesi tıp fakültesi'nde akılcı ilaç kullanımı stajının öğrenci bakış açısı ile değerlendirilmesi. Tip Eğitimi Dünyası. 2011;30:9-16.

2. Türk S. Diş Hekimliği Fakültesi öğrencilerine yönelik akılcı ilaç kullanımı anket çalışması. Yüksek Lisans Tezi, Mustafa Kemal Üniversitesi, Sağlık Bilimleri Enstitüsü, Hatay, 2018;1-2.

3. Hardon A, Prudon P, Reeler A. Toplumda ilaç kullanımı nasıl araştırılır? Ankara, Refik Saydam Hıfzıssıhha Merkezi Başkanlığı, 2004;1-3.

4. Çiçek Z. Sağlık inanç modeli doğrultusunda verilen eğitimin kadınların bilinçsiz ve reçetesiz ilaç kullanımı üzerine etkisi, Doktora Tezi, Atatürk Üniversitesi, Sağlık Bilimleri Enstitüsü, Erzurum,2012;4.

5. Göçer Ş. Sağlık inanç modeline göre verilen eğitimin yaşlı bireylerde bilinçli ilaç kullanımına etkisi. Doktora Tezi, Erciyes Üniversitesi, Sağllk Bilimleri Enstitüsü, Kayseri, 2018;12-15.

6. Ulusoy HB, Sumak T, Şahin S, Gültekin H. Kayseri'de pratisyen hekimlere verilen groningen modeli akılcı ilaç kullanımı eğitiminin değerlendirilmesi. Erciyes Tip Dergisi (Erciyes Medical Journal). 2011;33(4):309-316.

7. Aydın B, Gelal A. Akılıı ilaç kullanımı: yaygınlaştırılması ve tıp eğitiminin rolü. Dokuz Eylül Üniversitesi Tip Fakültesi Dergisi. 2012;26 (1):57-63.

8. Kayaalp O. Akılcı tedavi yönünden tıbbi farmakoloji. 13.baskı, Ankara, Pelikan Yayıncılık, 2012;140-154.

9. Sağır M, Parlakpınar H. Akılcı ilaç kullanımı. İnönü Üniversitesi Sağlık Bilimleri Dergisi. 2014;3(2):32-35.

10. Altındiş S. Akılcı ilaç kullanımına sistematik bir bakış. J Biotechnoland Strategic HealthRes. 2017;1(2):34-38.

11. T.C. Kalkınma Bakanlığı, Onuncu Kalkınma Planı 2014-2018 İlaç çalışma Grubu Raporu. Ankara,2014;3-5.

12. Sektörel Bakış İlaç 2019. https://assets.kpmg/content/dam/ kpmg/tr/pdf/2019/04/sektorel-bakis-2019-ilac.pdf. Erişim tarihi:12.12.2019

13. Maxwell S. Rational prescribing: the principles of drug selection. Clinical Medicine.2009;9:481-485.

14. Demirkıran M, Şahin B. Pratisyen hekimlerin ilaç seçimlerini etkileyen faktörlere ilişkin değerlendirmeleri. Hacettepe Sağlı İdaresi Dergisi. 2010;13(1):1-28.

15. Prosser H, Almond S, Walley T. Influences on gps' decision to prescribe new drugs-the importance of who says what". FamilyPractice. 2003;20(1):61-68.

16. T.C. Sağlık Bakanlığı Refik Saydam Hıfzıssıhha Merkezi Başkanlığı Hıfzıssıhha Mektebi Müdürlüğü. Hekimlerin Akılcı Reçeteleme Yaklaşımı. (HMM Yayın No: HMM-2011-37). Ankara, Yorum Basın Yayın Sanayii Ltd.Şt.2011;43-45.

17. Toklu HZ, Dülger GA. Akılıı ilaç kullanımı ve eczacının rolü. Marmara Pharmaceutical Journal.2001;15:89-93. 